\title{
The ligational behavior of an isatinic quinolyl hydrazone towards copper(II)- ions
}

\author{
Hussein S Seleem*, Gaber A El-Inany, Bashir A El-Shetary, Marwa A Mousa and Fatin I Hanafy
}

\begin{abstract}
Background: The importance of the isatinic quinolyl hydrazones arises from incorporating the quinoline ring with the indole ring. Quinoline ring has therapeutic and biological activities whereas, the indole ring occurs in Jasmine flowers and Orange blossoms. As a ligand, the isatin moiety is potentially ambidentate and can coordinate the metal ions either through its lactam or lactim forms. In a previous study, the ligational behavior of a phenolic quinolyl hydrazone towards copper(II)- ions has been studied. As continuation of our interest, the present study is planned to check the ligational behavior of an isatinic quinolyl hydrazone.

Results: New homo- and heteroleptic copper(II)- complexes were obtained from the reaction of an isatinic quinolyl hydrazone $(\mathrm{HL})$ with several copper(II)- salts viz. $\mathrm{Cl}^{-}, \mathrm{Br}^{-}, \mathrm{NO}_{3}{ }^{-}, \mathrm{ClO}_{4}{ }^{-}, \mathrm{SO}_{4}{ }^{2-}$ and $\mathrm{AcO}$. The obtained complexes have $\mathrm{O}_{\mathrm{h}}, \mathrm{T}_{\mathrm{d}}$ and $\mathrm{D}_{4 \mathrm{~h}^{-}}$symmetry and fulfill the strong coordinating ability of $\mathrm{Cl}^{-}, \mathrm{Br}^{-}, \mathrm{NO}_{3}{ }^{-}$and $\mathrm{SO}_{4}{ }^{2-}$ anions. Depending on the type of the anion, the ligand coordinates the copper(II)- ions either through its lactam $\left(\mathrm{NO}_{3}{ }^{-}\right.$and $\left.\mathrm{ClO}_{4}{ }^{-}\right)$or lactim (the others) forms.

Conclusion: The effect of anion for the same metal ion is obvious from either the geometry of the isolated complexes $\left(\mathrm{O}_{h}, T_{d}\right.$ and $\left.\mathrm{D}_{4 h}\right)$ or the various modes of bonding. Also, the obtained complexes fulfill the strong coordinating ability of $\mathrm{Cl}^{-}, \mathrm{Br}^{-}, \mathrm{NO}_{3}{ }^{-}$and $\mathrm{SO}_{4}{ }^{2-}$ anions in consistency with the donor ability of the anions. In case of copper(II)- acetate, a unique homoleptic complex (5) was obtained in which the $\mathrm{AcO}^{-}$anion acts as a base enough to quantitatively deprotonate the hydrazone. The isatinic hydrazone uses its lactim form in most complexes.
\end{abstract}

\section{Background}

Hydrazones and their metal complexes present innumerous pharmacological applications as antimicrobial, anticonvulsant, analgesic, anti-inflammatory, anti-tubercular and antitumor agents [1-3]. Also, the metal complexes of hydrazones have potential applications as catalysts [4], luminescent probes [5] and molecular sensors [6]. The importance of the isatinic quinolyl hydrazones arises from incorporating the quinoline ring with the indole ring. Quinoline ring has therapeutic and biological activities whereas, the indole ring occurs in Jasmine flowers and Orange blossoms [1-3]. As a ligand, the isatin moiety is potentially ambidentate and can coordinate the metal ions either through the lactam or lactim forms. In general, this study is planned to investigate the ligational behavior of the studied hydrazone (Scheme 1); 3-[2-(4,8-dimethylquinolin-2-yl)hydrazono] indolin-2-one (HL) towards several copper(II)- salts $\left(\mathrm{Cl}^{-}, \mathrm{Br}^{-}, \mathrm{NO}_{3}^{-}, \mathrm{ClO}_{4}^{-}, \mathrm{SO}_{4}{ }^{2-}\right.$ and $\left.\mathrm{AcO}^{-}\right)$. This work is an extension to our previous studies on the chelating ability of some quinolyl hydrazones [7-11].

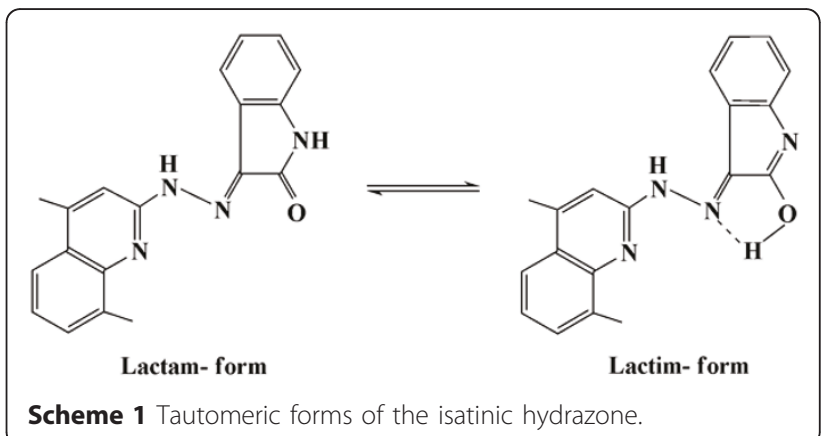

* Correspondence: hsseleem@yahoo.com

Department of Chemistry, Faculty of Education, Ain Shams University, Roxy, Cairo, Egypt 


\section{Results and discussion}

\section{Characterization of the hydrazone}

The investigated hydrazone (HL) was prepared by a condensation reaction of 2-hydrazinyl-4,8-dimethylquinoline with isatin (indol-2,3-dione). The results of elemental analysis (Table 1) are in good harmony with the proposed formula. The IR spectrum (Table 2) showed very strong bands at 3203 and $1605 \mathrm{~cm}^{-1}$ which are assigned to $v(\mathrm{NH})$ and $v(\mathrm{C}=\mathrm{N})$, respectively. The lactam nature of $\mathrm{HL}$ was supported by a very strong band at $1706 \mathrm{~cm}^{-1} ; v(\mathrm{C}=\mathrm{O})$. On the other hand, the electronic absorption spectra of the hydrazone in DMF exhibit two intense bands at 268 and $391 \mathrm{~nm}$ characteristic for $\pi-\pi *$ and charge transfer (CT) transitions. The latter band (CT) impact the ligand its red color whereas, the higher energy band is consistent with that reported for the aromatic quinoline ring [7-11]. The mass spectrum of the ligand showed the $\mathrm{M}^{+}$peak at $\mathrm{m} / z=316$ confirming its formula weight (316.36). The mass fragmentation pattern (Scheme 2) supported the suggested structure of the ligand. Finally, the ${ }^{1} \mathrm{H}$ NMR spectral data of the ligand in $\mathrm{d}_{6}$-DMSO relative to TMS; Figure 1, lend a further support of the structure.

\section{Characterization of the isatinic complexes}

The isatinic hydrazone (HL) has mainly two tautomeric forms (Scheme 1). Both rearrangements; the lactam-lactim forms are useful in explaining the different coordinating properties. The ligand was allowed to react with several copper(II)- salts viz. $\mathrm{Cl}^{-}, \mathrm{Br}^{-}, \mathrm{NO}_{3}{ }^{-}, \mathrm{SO}_{4}{ }^{2-}, \mathrm{ClO}_{4}{ }^{-}$ and $\mathrm{AcO}^{-}$in order to determine the effect of the anions on the formed products (Scheme 3 ). The obtained copper(II)- complexes reflect the strong coordinating power of $\mathrm{SO}_{4}{ }^{2-}, \mathrm{Cl}^{-}, \mathrm{Br}^{-}$and $\mathrm{NO}_{3}{ }^{-}$as compared to the weakly or non coordinating power of $\mathrm{ClO}_{4}{ }^{-}$. This is consistent with the donor ability of the anions [12-14]; $\left(\mathrm{DN}_{\mathrm{x}}=\right.$ 36.2, 33.7, 21.1 and 8.44 for $\mathrm{Cl}^{-}, \mathrm{Br}^{-}, \mathrm{NO}_{3}{ }^{-}$and $\mathrm{ClO}_{4}{ }^{-}$,

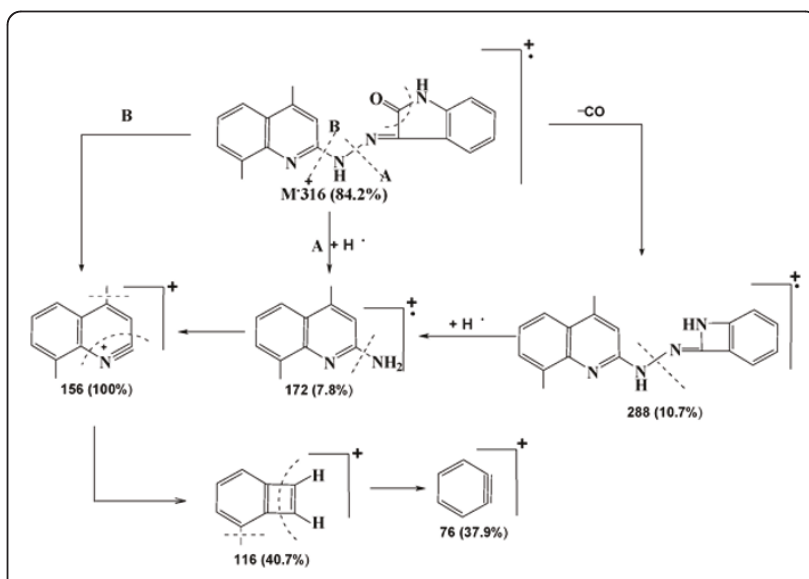

Scheme 2 Mass fragmentation pattern of the isatinic hydrazone.

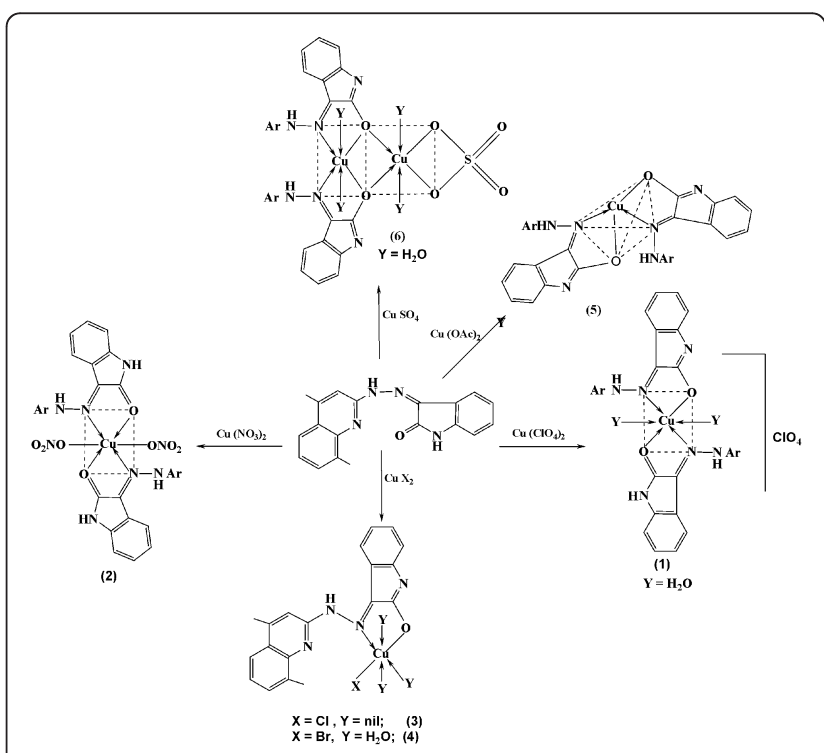

Scheme 3 Effect of anion on the copper(II) - isatinic complexes.

Table 1 Analytical and physical data of the copper(II)- isatinic complexes.

\begin{tabular}{|c|c|c|c|c|c|c|c|c|c|}
\hline \multirow[t]{2}{*}{ No. } & \multirow{2}{*}{$\begin{array}{l}\text { Reactants }(\mathrm{HL}+ \\
\text { metal salt) }\end{array}$} & \multirow[t]{2}{*}{ Complex (F.W.) } & \multirow[t]{2}{*}{ Color } & \multirow{2}{*}{$\begin{array}{c}\% \\
\text { Yield }\end{array}$} & \multirow{2}{*}{$\begin{array}{l}\text { m.p. } \\
\left({ }^{\circ} \mathrm{C}\right)\end{array}$} & \multicolumn{4}{|c|}{ Elemental Analysis; \% Found/(Calcd.) } \\
\hline & & & & & & C & $\mathrm{H}$ & $\mathrm{N}$ & $M$ \\
\hline & $\mathrm{HL}$ & $\mathrm{HL}\left(\mathrm{C}_{19} \mathrm{H}_{16} \mathrm{~N}_{4} \mathrm{O} ; 316.36\right)$ & Red & 60 & 300 & $\begin{array}{l}72.06 \\
(72.13)\end{array}$ & $\begin{array}{c}5.17 \\
(5.10)\end{array}$ & $\begin{array}{c}17.70 \\
(17.71)\end{array}$ & -- \\
\hline 1 & $\mathrm{Cu}\left(\mathrm{ClO}_{4}\right)_{2} \cdot 6 \mathrm{H}_{2} \mathrm{O}$ & $\begin{array}{c}{\left[\mathrm{Cu}(\mathrm{L})(\mathrm{HL})\left(\mathrm{H}_{2} \mathrm{O}\right)_{2}\right] \mathrm{ClO}_{4} .3 \mathrm{H}_{2} \mathrm{O}} \\
(884.79)\end{array}$ & Red & 60 & $\underset{300}{>}$ & $\begin{array}{c}51.54 \\
(51.58)\end{array}$ & $\begin{array}{l}4.63 \\
(4.67)\end{array}$ & $\begin{array}{c}12.69 \\
(12.67)\end{array}$ & $\begin{array}{c}7.25 \\
(7.18)\end{array}$ \\
\hline 2 & $\mathrm{Cu}\left(\mathrm{NO}_{3}\right)_{2} \cdot 21 / 2 \mathrm{H}_{2} \mathrm{O}$ & {$\left[\mathrm{Cu}(\mathrm{HL})_{2}\left(\mathrm{NO}_{3}\right)_{2}\right] .11 \frac{1}{4} \mathrm{H}_{2} \mathrm{O}(842.81)$} & Yellowish brown & 61 & $\underset{300}{>}$ & $\begin{array}{c}54.10 \\
(54.15)\end{array}$ & $\begin{array}{l}4.12 \\
(4.13)\end{array}$ & $\begin{array}{c}16.44 \\
(16.62)\end{array}$ & $\begin{array}{c}7.62 \\
(7.54)\end{array}$ \\
\hline 3 & $\mathrm{Cu} \mathrm{Cl} 2 \cdot 2 \mathrm{H}_{2} \mathrm{O}$ & 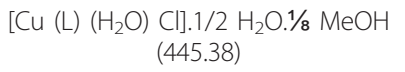 & Dark green & 30 & 252 & $\begin{array}{c}51.48 \\
(51.57)\end{array}$ & $\begin{array}{c}4.14 \\
(4.19)\end{array}$ & $\begin{array}{c}12.57 \\
(12.58)\end{array}$ & $\begin{array}{c}14.10 \\
(14.27)\end{array}$ \\
\hline 4 & $\mathrm{Cu} \mathrm{Br} 2$ & {$\left[\mathrm{Cu}(\mathrm{L})\left(\mathrm{H}_{2} \mathrm{O}\right)_{3} \mathrm{Br}\right] .3 / 8 \mathrm{H}_{2} \mathrm{O}(519.60)$} & $\begin{array}{l}\text { Granulated greenish } \\
\text { brown }\end{array}$ & 60 & $\underset{300}{>}$ & $\begin{array}{c}43.92 \\
(43.92)\end{array}$ & $\begin{array}{c}4.15 \\
(4.22)\end{array}$ & $\begin{array}{c}10.81 \\
(10.79)\end{array}$ & $\begin{array}{c}12.40 \\
(12.23)\end{array}$ \\
\hline 5 & $\mathrm{Cu}(\mathrm{OAc})_{2} \cdot \mathrm{H}_{2} \mathrm{O}$ & {$\left[\mathrm{Cu}(\mathrm{L})_{2}\right] .1 / 8 \mathrm{H}_{2} \mathrm{O} .1 / 8 \mathrm{MeOH}(700.51)$} & $\begin{array}{l}\text { Bright greenish } \\
\text { brown }\end{array}$ & 82 & 292 & $\begin{array}{c}65.47 \\
(65.36)\end{array}$ & $\begin{array}{c}4.51 \\
(4.42)\end{array}$ & $\begin{array}{c}15.93 \\
(15.99)\end{array}$ & $\begin{array}{c}8.90 \\
(9.07)\end{array}$ \\
\hline 6 & $\mathrm{Cu} \mathrm{SO} \cdot 5 \mathrm{H}_{2} \mathrm{O}$ & {$\left[\begin{array}{cc}{\left[\mathrm{Cu}_{2}(\mathrm{~L})_{2}\left(\mathrm{H}_{2} \mathrm{O}\right)_{4} \mathrm{SO}_{4}\right] \cdot 2 \mathrm{H}_{2} \mathrm{O} \cdot \mathrm{MeOH}} \\
(994)\end{array}\right.$} & Dark orange & 64 & $\underset{300}{>}$ & $\begin{array}{c}47.12 \\
(47.12)\end{array}$ & $\begin{array}{c}4.69 \\
(4.66)\end{array}$ & $\begin{array}{c}11.13 \\
(11.28)\end{array}$ & $\begin{array}{c}12.70 \\
(12.79)\end{array}$ \\
\hline
\end{tabular}


Table 2 Magnetic, conductivity, electronic and IR spectral data of the copper(II)- isatinic complexes.

\begin{tabular}{|c|c|c|c|c|c|c|c|}
\hline \multirow[t]{2}{*}{ Complex } & \multirow[t]{2}{*}{$\lambda(\mathrm{nm})$} & \multirow[t]{2}{*}{$\mu_{\text {eff }}$ B.M. } & \multirow[t]{2}{*}{ Conductance $\Omega^{-1} \mathrm{~cm}^{2} \mathrm{~mol}^{-1}$} & \multicolumn{4}{|c|}{ IR spectral bands; $\mathrm{cm}^{-1}$} \\
\hline & & & & $v(\mathrm{NH})$ & $v(C=0)$ & $v(C=N)$ & Others \\
\hline $\mathrm{HL}$ & 268,391 & --- & - & 3203 & 1706 & 1605 & -—— \\
\hline 1 & 396 & 1.80 & 95.0 & 3287 & 1653 & 1627 & $1100 ; v_{3}(\mathrm{ClO})$ \\
\hline 2 & 396 & 1.93 & 12.0 & 3463 & 1692 & 1623 & 1387 and $1297 ; v(\mathrm{NO})$ \\
\hline 3 & 391 & 1.87 & 37.0 & 3235 br. & -- & 1619 & -—-— \\
\hline 4 & 392 & 1.82 & 40.0 & 3203 br. & -—— & 1621 & -—— \\
\hline 5 & 453 & 1.77 & Zero & 3363 & - - & 1608 & -—- \\
\hline 6 & 450 & 1.40 & 15.0 & 3273 & - - & 1633 & $1135 ; v_{3}(\mathrm{SO})$ \\
\hline
\end{tabular}

respectively). All complexes are mononuclear except complex 6 which is binuclear. The obtained complexes have the octahedral $\left(\mathrm{O}_{\mathrm{h}}\right)$, tetrahedral $\left(\mathrm{T}_{\mathrm{d}}\right)$ and square planar $\left(\mathrm{D}_{4 \mathrm{~h}}\right)$ geometry; (Scheme 3 ) and reflect the non participation of the heterocyclic $\mathrm{N}$ - atom of the quinoline ring in the chelation. The isatinic hydrazone (HL) behaves as monoanionic or neutral NO- donor which is consistent with steric properties of the more rigid ligand. Characterization of the obtained complexes was achieved via elemental and thermal analyses, magnetic and conductivity measurements as well as spectral studies.

\section{IR spectra of the complexes}

The mode of bonding was studied by comparing the IR spectral bands of the metal complexes with those of the

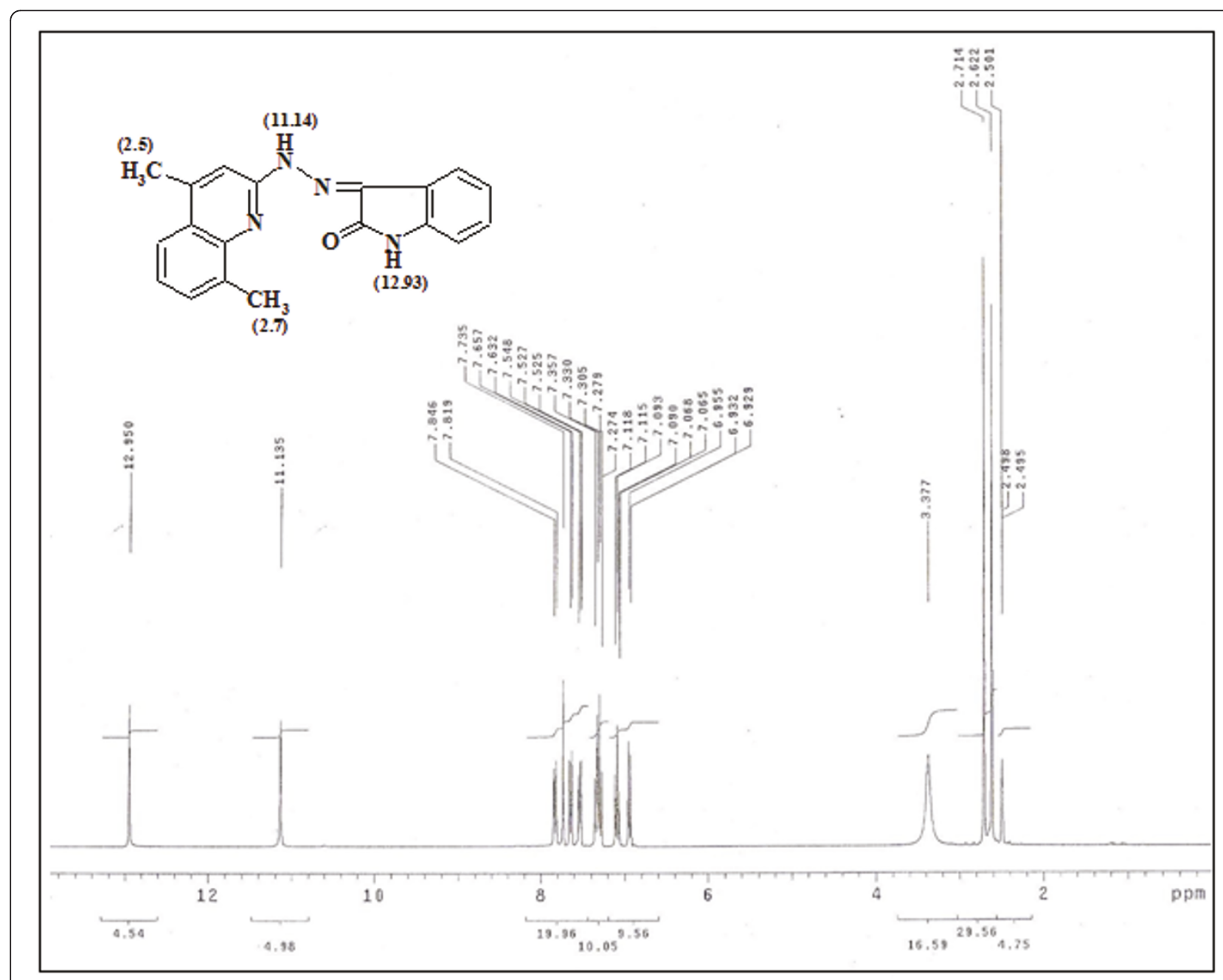

Figure $1{ }^{1} \mathrm{HNMR}$ spectrum of the isatinic hydrazone; $\delta=6.96-7.74$ for aromatic protons $(8 \mathrm{H})$ 
free ligand (Table 2). Inspection of the data revealed the following: (i) All complexes showed a broad band in the range $3463-3203 \mathrm{~cm}^{-1}$ due to $v(\mathrm{OH})$ of the associated water or methanol molecules. (ii) The band at $1605 \mathrm{~cm}^{-1}$ assignable to $v(\mathrm{C}=\mathrm{N})$ in the free ligand was shifted to higher values indicating the participation of $\mathrm{C}=\mathrm{N}$ of the hydrazone moiety in the chelation with $\pi$ - electron delocalization. (iii) In most complexes, the band located at 1706 $\mathrm{cm}^{-1}$ due to $v(\mathrm{C}=\mathrm{O})$ of the free ligand disappeared indicating the participation of the lactim- form in the chelation. In contrast, the lactam- form participates in the chelation in case of the nitrato (2) and perchlorato (1) complexes as indicated by the shift of the above band to lower wave numbers; 1692 and $1653 \mathrm{~cm}^{-1}$, respectively. However, the greater lower value $1653 \mathrm{~cm}^{-1}$ for the perchlorate complex (1) may suggest mixed modes of bonding (lactim + lactam) [7]; Scheme 3. (iv) In complex 1, the strong broad band centered at $1100 \mathrm{~cm}^{-1}$ (antisymmetric stretch) and the sharp band at $621 \mathrm{~cm}^{-1}$ (antisymmetric bend) suggest uncoordinated $\mathrm{ClO}_{4}{ }^{-}$anion [14]. (v) For the binuclear sulfato complex (6), the chelating bidentate nature of the $\mathrm{SO}_{4}{ }^{2-}$ group is indicated by the appearance of $v_{3}(\mathrm{~S}-\mathrm{O})$ strong band at $1135 \mathrm{~cm}^{-1}$ characteristic for the high symmetry $\mathrm{T}_{\mathrm{d}}$ (tetrahedral) point group. The nitrato complex (2) showed two bands at 1387 and $1297 \mathrm{~cm}^{-1}$ confirming the monodentate nature of the coordinated $\mathrm{NO}_{3}{ }^{-}$group; $\mathrm{C}_{2 \mathrm{v}}$ symmetry. (vi) Finally, the detection of the non ligand bands; $v(\mathrm{M}-\mathrm{O})$ and $v(\mathrm{M}-\mathrm{N})$ in the finger print region is more difficult and tentative.

\section{Conductivity and magnetic properties}

The recorded conductance for $10^{-3}$ molar DMF solutions of the complexes (Table 2) indicates that all complexes are non-conducting due to their neutrality $(\Lambda=17.0-1.9$ $\left.\Omega^{-1} \mathrm{~cm}^{2} \mathrm{~mol}^{-1}\right)$. The only exception is $\left[\mathrm{Cu}(\mathrm{L})(\mathrm{HL})\left(\mathrm{H}_{2} \mathrm{O}\right)\right.$ ${ }_{2} \mathrm{ClO}_{4} \cdot 3 \mathrm{H}_{2} \mathrm{O}(\mathbf{1})$ which showed molar conductance of 95 $\Omega^{-1} \mathrm{~cm}^{2} \mathrm{~mol}^{-1}$, indicating its 1:1 electrolytic nature which is consistent with the IR spectra; $v_{3}(\mathrm{Cl}-\mathrm{O})$ at $1100 \mathrm{~cm}^{-1}$. In contrast, the halo-complexes ( 3 and $\mathbf{4}$ ) showed molar conductance of 37 and $40 \Omega^{-1} \mathrm{~cm}^{2} \mathrm{~mol}^{-1}$, respectively indicating their partial electrolytic nature which is due to the replacement of the coordinated $\mathrm{Cl}^{-}$and $\mathrm{Br}^{-}$ions by DMF solvent molecules [4]. On the other side, the effective magnetic moments ( $\mu_{\text {eff }}$ ) of the copper(II)- complexes (1-5) lie in the range 1.93-1.77 B.M. (Table 2) which is consistent with one unpaired electron and falls within the range reported for mononuclear copper(II)complexes. However, the binuclear copper(II)- complex (6) exhibits lower $\mu_{\text {eff }}$ value at 1.4 B.M. indicating some metal-metal interaction.

\section{Mass and electronic spectra}

The mass spectra of complexes 3; [Cu $\left.(\mathrm{L})\left(\mathrm{H}_{2} \mathrm{O}\right) \mathrm{Cl}\right] .1 / 2$ $\mathrm{H}_{2} \mathrm{O} .1 / 8 \mathrm{MeOH}(445.38)$ and $4 ;\left[\mathrm{Cu}(\mathrm{L})\left(\mathrm{H}_{2} \mathrm{O}\right)_{3} \mathrm{Br}\right] .3 / 8$
$\mathrm{H}_{2} \mathrm{O}(519.60)$ as representative examples showed their molecular ion and base peaks at $\mathrm{m} / \mathrm{e}$ (447 and 156) and (519 and 45), respectively, confirming their suggested structures. On the other side, the electronic spectra of the complexes as DMF solutions showed a new intense broad band in the range 391-453 nm confirming its charge transfer (CT) nature (Figure 2 and Table 2). Therefore, the type of the $\mathrm{d}$ - $\mathrm{d}$ transitions can not be identified due to the strong CT bands tailing from UV region to the visible region. In general, the color of all complexes is dominated by the CT transition which obscured the weak $\mathrm{d}-\mathrm{d}$ transition occurring in the same region; a phenomenon encountered with isatinic complexes [4]. Also, the electronic spectra of all complexes are nearly similar in terms of the position, intensity and shape of the bands (Figure 2 and Table 2).

\section{Electron spin resonance spectroscopy}

The ESR spectra of $\left[\mathrm{Cu}(\mathrm{L})(\mathrm{HL})\left(\mathrm{H}_{2} \mathrm{O}\right)_{2}\right] \mathrm{ClO}_{4} \cdot 3 \mathrm{H}_{2} \mathrm{O}(\mathbf{1})$ and $\left[\mathrm{Cu}(\mathrm{L})_{2}\right] .1 / 8 \mathrm{H}_{2} \mathrm{O} .1 / 8 \mathrm{MeOH}(5)$; Figure 3 are largely different, however, the ESR spectral profile of complex $\mathbf{5}$ confirms its $\mathrm{T}_{\mathrm{d}}$ geometry. Generally, ESR spectra are useful for distinguishing square planar and tetrahedral geometries. The ESR spectral parameters were used to evaluate the bonding parameters $\alpha^{2}$ and $\beta^{2}$ which may be regarded as a measure of the in-plane $\sigma$ - bonding and the in-plane $\pi$ bonding, respectively. The following simplified expressions were used to evaluate the bonding parameters $[15,16]$ :

$$
\alpha^{2}=\left[\mathrm{E}\left(g_{11}-g_{e}\right)\right] / 8 v \beta^{2} \text { and } \beta^{2}=\left[E\left(g_{\perp}-g_{e}\right)\right] / 2 v \gamma^{2}
$$

where $\mathrm{E}$ is the transition energy, $v$ represents the electron spin-orbit coupling and $\gamma^{2}$ represents the out-ofplane $\pi$-bonding and was taken as a constant value. On the other hand, the super-exchange splitting constant $A_{11}$ was evaluated from the following expression:

$$
\alpha^{2}=\left(\frac{A_{11}}{P}\right)+\left(g_{11}-g_{\perp}\right)+\frac{3}{7}\left(g_{\perp}-g_{e}\right)+0.04
$$

where $\mathrm{P}$ is the free ion dipolar term and its value depends on the type of the metal ion. Also, the $f$ - factor ( $\left.f=g_{11} / A_{11}\right)$ was evaluated to determine the extent of tetragonal distortion. The obtained ESR parameters are shown in Table 3.

In summary, the $\mathrm{T}_{\mathrm{d}}$ - complex (5) with the lactim mode showed either higher values of $\mathrm{G}, \alpha^{2}, K_{\Pi}^{2}$ and $f$ or lower values of $\beta^{2}$ and $A_{\Pi}$ as compared to the $\mathrm{O}_{\mathrm{h}}$ complex (1) with the mixed mode (lactam + lactim) which is consistent with the greater discrepancy of the observed spectra.

\section{Thermal (TG-DSC) analysis}

The thermal degradation behavior of the investigated complexes was followed by the thermogravimetric (TG) 


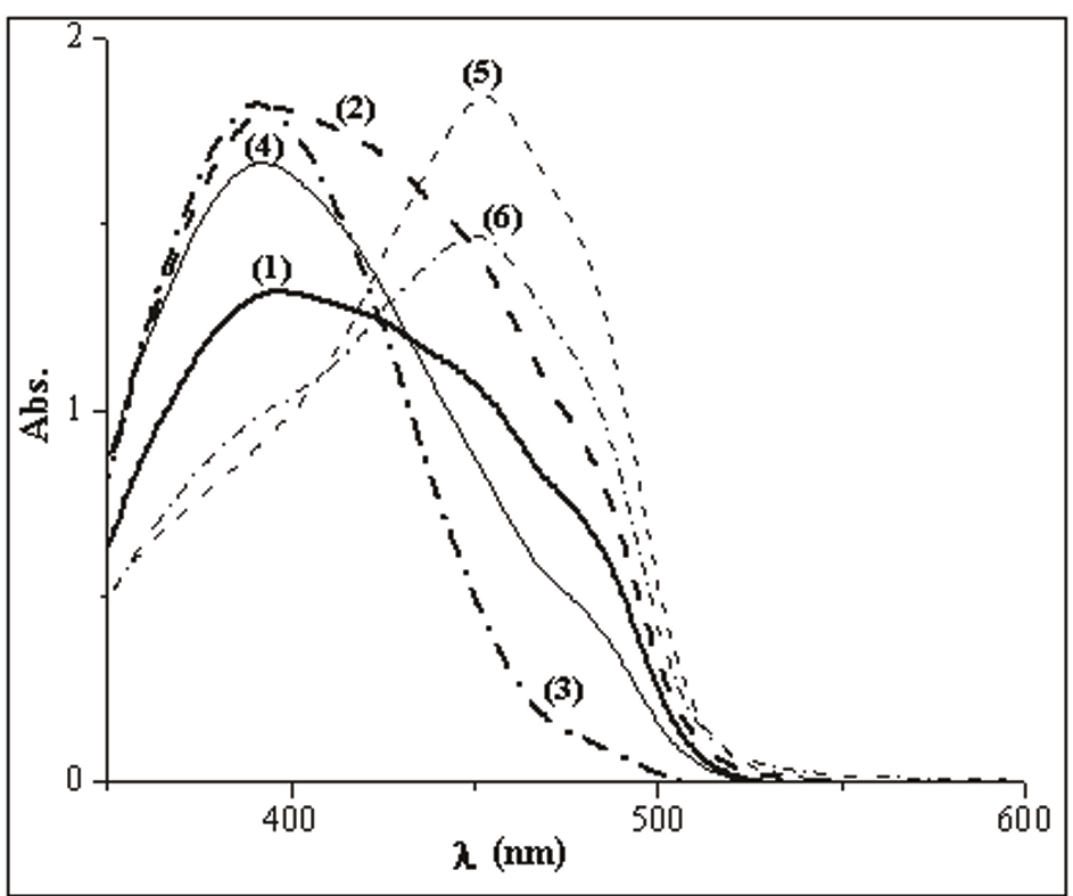

Figure 2 Overlay of the electronic spectra of the copper(II)-complexes.

and differential scanning calorimetric (DSC) techniques. The decomposition occurs in one or more steps according to the nature of each complex. Attempts to generalize the thermal degradation patterns were unsuccessful indicating that there is no simple relation or general trend for explaining these thermal degradations. However, the decomposition ends with the formation of $\mathrm{Cu}_{2} \mathrm{O}$ in most cases. Inspection of the TG thermograms revealed the following: (i) The perchlorato complex (1) decomposes in one strong endothermic step $\left(\Delta \mathrm{H}=391 \mathrm{~J} / \mathrm{g}\right.$ at $\left.272^{\circ} \mathrm{C}\right)$ to form $\mathrm{Cu}_{2} \mathrm{O}$ as the end product, a phenomenon encountered with $\mathrm{ClO}_{4}{ }^{-}$anions [14]. (ii) For the nitrato- (2) and sulfato (6)- complexes, the decomposition is not completed up to $800^{\circ} \mathrm{C}$, indicating that the metal-ligand bonds are strong. This is consistent with the data extracted from IR. (iii) In contrast, for the other complexes $(1,4 \& 5)$, the decomposition process is ended with $\mathrm{Cu}_{2} \mathrm{O}$.

\section{Kinetic and thermodynamic parameters}

The activation energy $\left(E^{*}\right)$ of decomposition of the complexes as well as the pre-exponential factor (A) were evaluated graphically using the Coats-Redfern equation;

$$
\ln \left[\frac{-\ln (1-\alpha)}{T^{2}}\right]=\frac{-E^{*}}{R T}+\ln \left[\frac{A R}{\phi E^{*}}\right]
$$

where $\alpha$ is the fraction of sample decomposed at temperature T, A the pre-exponential factor, $\phi$ the heating rate, $E^{*}$ the activation energy and $R$ the gas constant. A plot of $\ln \left[-\ln (1-\alpha) / \mathrm{T}^{2}\right]$ against $1 / \mathrm{T}$ gives a straight line whose slope $=-E^{*} / \mathrm{R}$ and its intercept $=\ln [\mathrm{AR} / \phi$ $\left.E^{*}\right]$; a sample set (Figure 4). The activation entropy, enthalpy and free energy changes of the decomposition were calculated by the following equations.:

$$
\Delta \mathrm{S} *=2.303 \mathrm{R} \log (\mathrm{Ah} / \mathrm{KT}), \Delta \mathrm{H} *=\mathrm{E} *-\mathrm{RT} \text { and } \Delta \mathrm{G} *=\Delta \mathrm{H} *-\mathrm{T} \Delta \mathrm{S} *
$$

where $\mathrm{h}, \mathrm{K}$ and $\mathrm{T}$ are the Planck's constant, Boltzmann's constant and the mid temperature in the TGthermogram, respectively. The calculated values of $\mathrm{A}$, $E^{*}, \Delta S^{*}, \Delta H^{*}$ and $\Delta G^{*}$ for the decomposition steps are given in Table 4. Inspection of the data revealed the following remarks: (i) The pre-exponential factor (collision factor; A) showed a direct relation to the activation energy $E_{a}$. (ii) The non spontaneity and endothermicity of the degradation processes. (iii) The perchlorato complex (1); $\left[\mathrm{Cu}(\mathrm{L})(\mathrm{HL})\left(\mathrm{H}_{2} \mathrm{O}\right)_{2}\right] \mathrm{ClO}_{4} \cdot 3 \mathrm{H}_{2} \mathrm{O}$ which decomposes in one sudden step has abnormal higher values of $\mathrm{A}, \mathrm{E}^{*}$ and $\Delta \mathrm{H}^{*}$ [7]. Also, it has a unique positive $\Delta S^{*} \sim$ $60 \mathrm{~J} \mathrm{~mol}^{-1} \mathrm{~K}^{-1}$ which is consistent with the formation of several species upon the sudden decomposition. (iv) In contrast, $\Delta S^{*}$ has negative values for all the other complexes indicating that the activated species are more ordered than the reactants [17-19].

\section{Biological activity}

The isatinic hydrazone and its copper(II)- complexes (1-6) were screened for both antibacterial and 

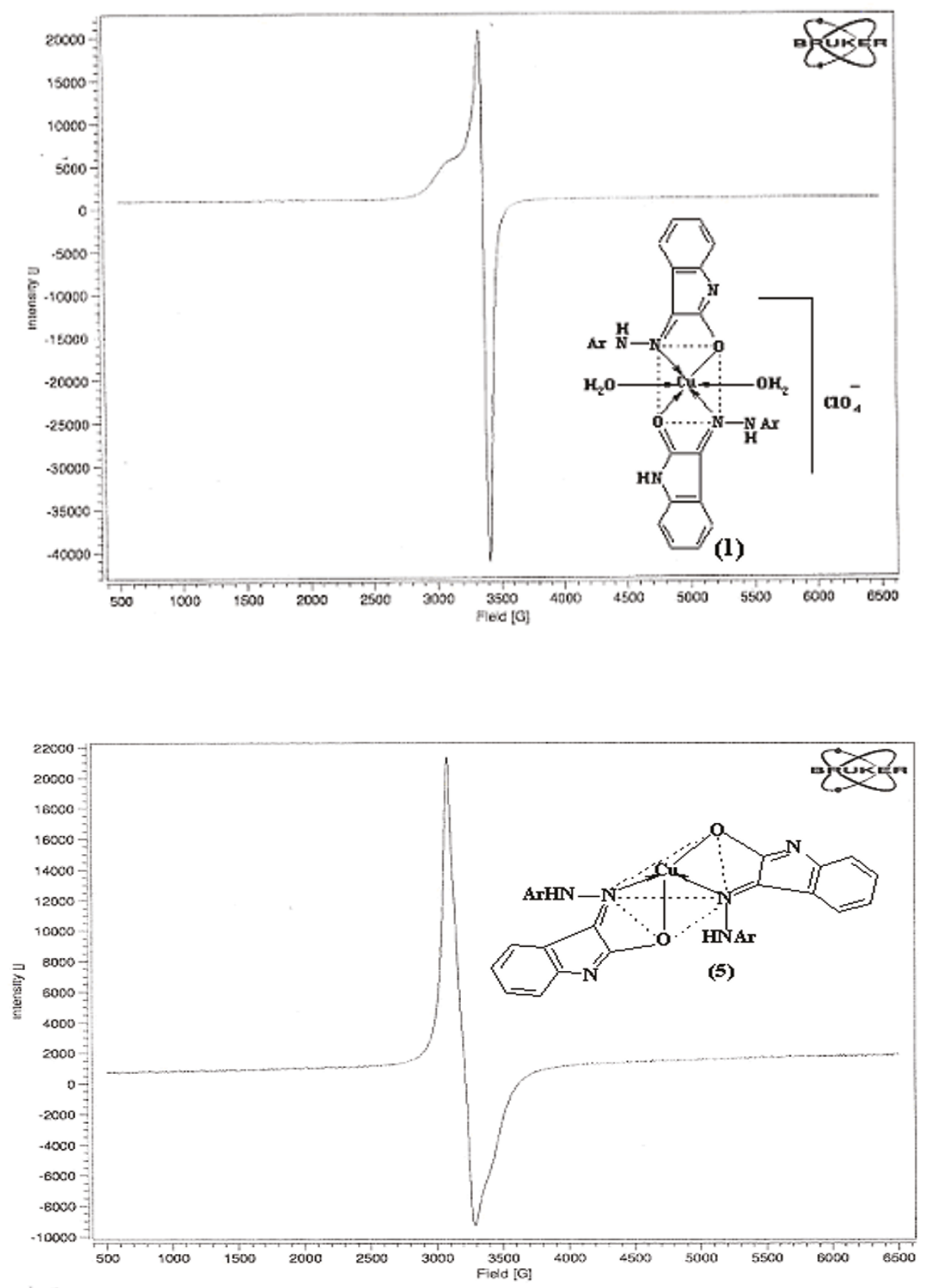

Figure 3 The X-band ESR spectra of complexes $1\left(O_{h}\right)$ and $5\left(T_{d}\right)$.

Table 3 ESR parameters

\begin{tabular}{cccccccccc}
\hline Complex & $\boldsymbol{g}_{\mathbf{1 1}}$ & $\boldsymbol{g}_{\perp}$ & $\mathbf{< g}$ & $\mathbf{G}$ & $\mathbf{A}^{\mathbf{2}}$ & $\boldsymbol{\beta}^{\mathbf{2}}$ & $\boldsymbol{K}_{\boldsymbol{\Pi}}^{\mathbf{2}}$ & $\left(\boldsymbol{A}_{\mathbf{1 1}}\right) \mathbf{c m}^{\mathbf{- 1}}$ & $\boldsymbol{f}$ \\
\hline$(\mathbf{1}) ; \mathrm{O}_{\mathrm{h}}$ & 2.174 & 2.076 & 2.109 & 2.033 & 0.582 & 0.534 & 0.311 & $154 \times 10^{-4}$ \\
$(\mathbf{5}) ; T_{\mathrm{d}}$ & 2.187 & 2.052 & 2.097 & 3.716 & 0.93 & 0.36 & 0.335 & $61 \times 10^{-4}$ & 362 \\
\hline
\end{tabular}




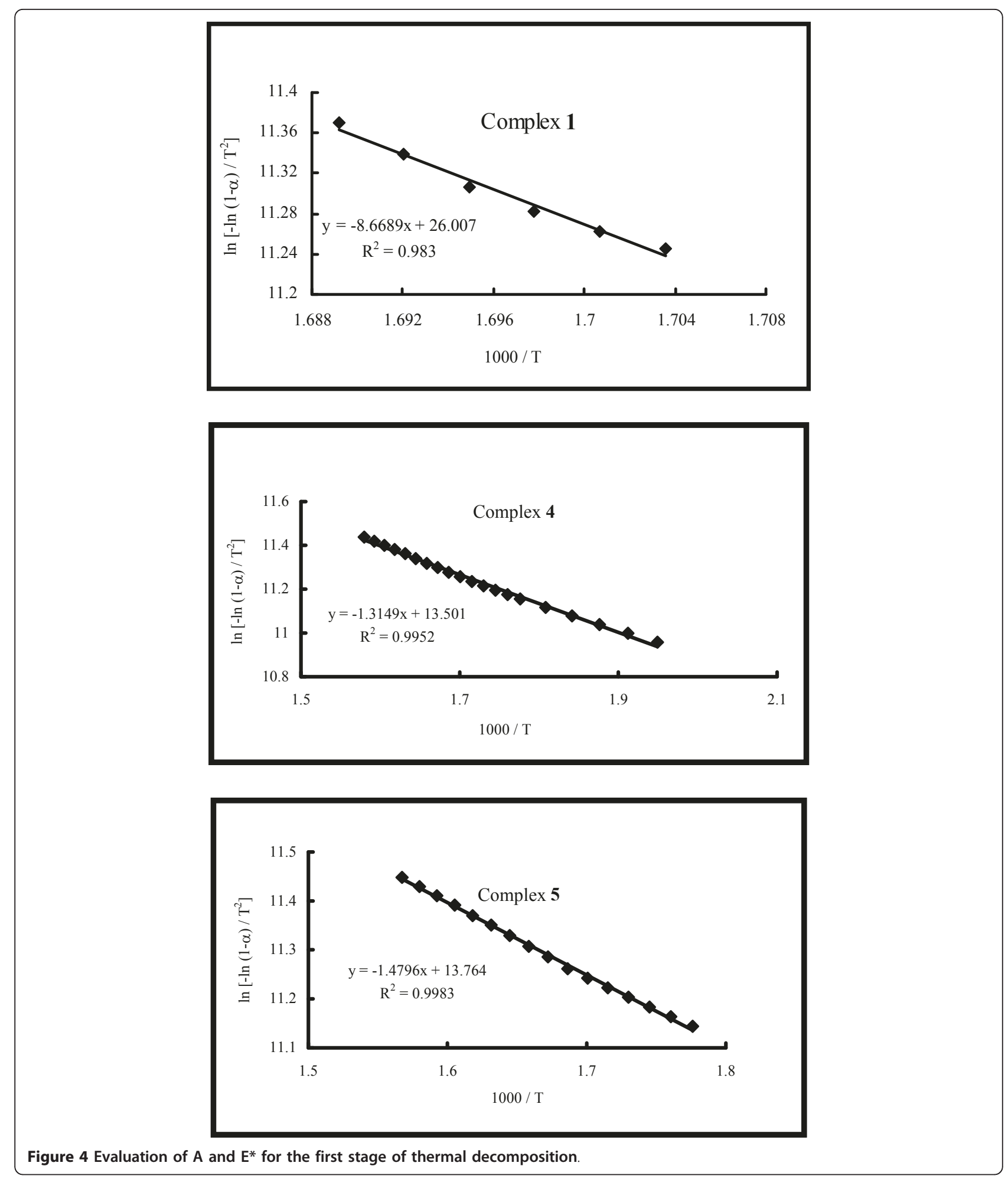

antifungal activities (Table 5). Inspection of the data revealed that all complexes lack the activity towards the fungus; Fusarium oxysporum. Also, the ligand and its complexes $(\mathbf{1}, \mathbf{4}$ and $\mathbf{5})$ lack the antimicrobial and antifungal activities. On the other hand, only the chloro-complex (3) has high activity against Grampositive bacteria ( $S$. aureus $\mathcal{E} S$. pyogenes) relative to the nitrato-complex (2). Also, the sulfato-complex (6) 
Table 4 Thermodynamic and kinetic parameters ${ }^{a}$ of the copper(II)- isatinic complexes.

\begin{tabular}{cccccccc}
\hline Complex & Stage & $\begin{array}{c}\mathrm{T} \\
(\mathrm{K})\end{array}$ & $\begin{array}{c}\mathrm{A} \times \mathbf{1 0}^{-\mathbf{9}} \\
\mathbf{s e c}^{-\mathbf{1}}\end{array}$ & $\mathrm{E}^{*}$ & $\Delta \mathrm{H}^{*}$ & $\Delta \mathrm{G}^{*}$ & $-\boldsymbol{\Delta} \mathrm{S}^{*}$ \\
\hline $\mathbf{1}$ & $1^{\text {st }}$ & 592 & $1.709 \times 10^{7}$ & 71.952 & 67.038 & 31.487 & -60.053 \\
$\mathbf{2}$ & $1^{\text {st }}$ & 355 & 1.486 & 5.942 & 2.996 & 28.082 & 70.667 \\
& $2^{\text {nd }}$ & 475 & 5.627 & 9.123 & 5.18 & 34.644 & 62.029 \\
$\mathbf{4}$ & $1^{\text {st }}$ & 590 & 9.601 & 10.914 & 6.017 & 41.059 & 59.393 \\
$\mathbf{5}$ & $1_{-}^{\text {st }}$ & 602 & 14.053 & 12.281 & 7.284 & 41.235 & 56.398 \\
\hline${ }^{\mathrm{a}} \mathrm{E}^{*}, \Delta \mathrm{H}^{*}$ and $\Delta \mathrm{G}^{*}$ are in k J mol ${ }^{-1}$ while $\Delta \mathrm{S}^{*}$ is in $\mathrm{J} \mathrm{mol}^{-1} \mathrm{~K}^{-1}$. & &
\end{tabular}

exhibited some activity towards Gram-negative bacteria (P. phaseolicola \& P. fluorescens) as well as the Fungus; Aspergillus fumigatus. In general, the antibacterial results (Table 5) suggest low activity as compared to the standard references (control) and depend mainly on type of the coordinated anion in consistency with our previous studies $[14,20]$.

\section{Experimental Materials}

The chemicals used in this investigation were of the highest purity available (Merck, BDH, Aldrich and Fluka). They included copper(II)- nitrate, perchlorate, sulfate, chloride, bromide and acetate as well as $o$-toluidine, ethyl acetoacetate, phosphorus oxychloride, hydrazine hydrate and isatin. Organic solvents were reagent grade chemicals and were used without further purification.

\section{Measurements}

Microanalyses were carried out on a Perkin-Elmer 2400 CHN elemental analyzer. Thermal analyses (TG-DSC) were carried out on a Shimadzu-50 thermal analyzer. Electronic spectra were recorded on a Jasco V-550 UV/ VIS spectrophotometer. IR spectra were recorded on a Bruker Vector 22 spectrometer using $\mathrm{KBr}$ pellets. ESR spectra were recorded on a Bruker Elexsys, E 500 operated at X-band frequency. Mass spectra were recorded either at $70 \mathrm{eV}$ on a gas chromatographic GCMSQP 1000-EX Shimadzu mass spectrometer or Direct Inlet unit (DI-50) of Shimadzu GC/MS - QP5050A. ${ }^{1} \mathrm{H}$ NMR spectra were recorded as DMSO- $\mathrm{d}_{6}$ solutions on a
Varian Mercury VX-300 NMR spectrometer using TMS as a reference. Molar conductivity was measured as DMF solutions on the Corning conductivity meter NY 14831 model 441. Magnetic susceptibility of the complexes was measured at room temperature using a Johnson Matthey, MKI magnetic susceptibility balance. Melting points were determined using a Stuart melting point apparatus.

\section{Preparation of the hydrazone [9-11]}

An ethanolic mixture of 2-hydrazinyl-4,8-dimethyl quinoline $(0.01 \mathrm{~mol})$ and isatin $(0.012 \mathrm{~mol})$ was refluxed for $1 / 2 \mathrm{~h}$. The formed red compound was filtered off, washed with ethanol and crystallized from DMF. The results of elemental analysis, $\%$ yield and m.p ${ }^{\circ} \mathrm{C}$ are shown in Table 1.

\section{Preparation of the metal complexes}

Methanolic solutions of the metal salt and the ligand were mixed in the mole ratio $1: 1$ and/or $1: 2$; $\mathrm{M}: \mathrm{L}$ and refluxed for 6-10 hours depending on the nature of the isolated complexes. The resulting precipitates were filtered off, washed with methanol then ether and finally air-dried. The results of elemental analysis, \% yield and m. $\mathrm{p}^{\circ} \mathrm{C}$ are shown in Table 1 .

\section{Antimicrobial and antifungal activities}

The standardized disc-agar diffusion method was followed to determine the activity of the synthesized compounds against the sensitive organisms Staphylococcus aureus (ATCC 25923) and Streptococcus pyogenes (ATCC 19615) as Gram-positive bacteria, Pseudomonas fluorescens (S 97) and Pseudomonas Phaseolicola (GSPB 2828) as Gram-negative bacteria and the Fungi Fusarium oxysporum and Aspergillus fumigatus. The antibiotic chloramphencol and Cephalothin were used as standard references in case of Gram-negative and Gram-positive bacteria, respectively, whereas Cycloheximide was used as a standard antifungal reference. The tested compounds were dissolved in DMF which have no inhibition activity to get concentration of $2 \mathrm{mg} / \mathrm{mL}$. The test was performed on medium potato dextrose agar (PDA) which contain infusion of $200 \mathrm{~g}$ potatoes, 6

Table 5 The biological activity* of HL and its copper(II)- complexes.

\begin{tabular}{cccccc}
\hline \multirow{2}{*}{ Organisms } & \multicolumn{5}{c}{ \% inhibition } \\
\cline { 2 - 6 } & \multicolumn{2}{c}{ Gram - positive bacteria } & Gram - negative bacteria & Fungus \\
\cline { 2 - 6 } & S. aureus & S. pyogenes & P. Phaseolicola & P. fluorescens & Aspergillus fumigatus \\
\hline $\mathrm{HL}$ & - & - & - & - & - \\
$(\mathbf{2})$ & 7 & - & - & - & - \\
$(3)$ & 24 & 22 & - & - & - \\
$(\mathbf{6})$ & - & - & 9 & 22 & 18 \\
\hline
\end{tabular}


$\mathrm{g}$ dextrose and $15 \mathrm{~g}$ agar. Uniform size filter paper disks (3 disks per compound) were impregnated by equal volume $(10 \mu \mathrm{L})$ from the specific concentration of dissolved tested compounds and carefully placed on inoculated agar surface. After incubation for $36 \mathrm{~h}$ at $37^{\circ} \mathrm{C}$ in case of bacteria and for three days at $25^{\circ} \mathrm{C}$ in case of fungi, inhibition of the organisms which evidenced by clear zone surround each disk was measured and used to calculate mean of inhibition zones.

\section{Conclusion}

The present study is planned to check the effect of the counteranions on the isolated complexes as well as the ligational behavior of the isatinic hydrazone ligand. The effect of anion for the same metal ion is obvious from either the geometry of the isolated complexes $\left(\mathrm{O}_{\mathrm{h}}, \mathrm{T}_{\mathrm{d}}\right.$ and $\mathrm{D}_{4 \mathrm{~h}}$ ) or the various modes of bonding. Also, the obtained complexes fulfill the strong coordinating ability of $\mathrm{Cl}^{-}, \mathrm{Br}^{-}, \mathrm{NO}_{3}{ }^{-}$and $\mathrm{SO}_{4}{ }^{2-}$ anions as compared to the $\mathrm{ClO}_{4}{ }^{-}$anion in consistency with the donor ability of the anions [12]. In case of copper(II)- acetate, a unique homoleptic complex (5) was obtained in which the $\mathrm{AcO}^{-}$anion acts as a base enough to quantitatively deprotonate the hydrazone. The isatinic hydrazone uses its lactim form in most complexes.

\section{Authors' contributions \\ HSS conceived the study, participated in the sequence alignment and drafted the manuscript. GAE and BAE participated in the design of the study, analysis of the data and modification of the manuscript. HSS and MAM isolated and characterized the complexes. FlH prepared and characterized the organic ligand. All authors read and approved the final manuscript.}

\section{Competing interests}

The authors declare that they have no competing interests.

Received: 5 February 2011 Accepted: 19 April 2011

Published: 19 April 2011

\section{References}

1. Tamasi G, Chiasserini L, Savini L, Sega A, Cini R: Structural study of ribonucleotide reductase inhibitor hydrazones. Synthesis and X-ray diffraction analysis of a copper(III-benzoylpyridine-2-quinolinyl hydrazone complex. J Inorg Biochem 2005, 99:1347-1359

2. Gupta LK, Bansal U, Chandra S: Spectroscopic approach in the characterization of the copper(II) complexes of isatin-3,2'-quinolylhydrazones and their adducts. Spectrochim Acta (A) 2006, 65:463-466

3. Gupta LK, Bansal U, Chandra S: Spectroscopic and physicochemical studies on nickel(II) complexes of isatin-3,2'-quinolyl-hydrazones and their adducts. Spectrochim Acta (A) 2007, 66:972-975.

4. Pouralimardan O, Chamayou A, Janiak C, Monfared H: Hydrazone Schiff base-manganese(II) complexes: Synthesis, crystal structure and catalytic reactivity. Inorg Chim Acta 2007, 360:1599-1608.

5. Basu C, Chowdhury S, Banerjee R, Evans HS, Mukherjee S: A novel blue luminescent high-spin iron(III) complex with interlayer $\mathrm{O}-\mathrm{H} . . . \mathrm{Cl}$ bridging: Synthesis, structure and spectroscopic studies. Polyhedron 2007, 26:3617-3624.

6. Bakir M, Green O, Mulder WH: Synthesis, characterization and molecular sensing behavior of $\left[\mathrm{ZnCl}_{2}\left(n^{3}-\mathrm{N}, \mathrm{N}, \mathrm{O}-\mathrm{dpkbh}\right)\right](\mathrm{dpkbh}=\mathrm{di}-2$-pyridyl ketone benzoyl hydrazone). J Mol Struct 2008, 873:17-28.
7. Seleem HS, El-Inany GA, El-Shetary BA, Mousa MA: The ligational behavior of a phenolic quinolyl hydrazone towards copper(II)- ions. Chemistry Central Journal 2011, 5:2

8. Seleem HS, Mostafa M, Hanafy Fl: Stability of transition metal complexes involving three isomeric quinolyl hydrazones. Spectrochim Acta (A) 2011, 78:1560-6.

9. Seleem HS, El-Inany GA, Eid MF, Mousa M, Hanafy Fl: Complexation of some hydrazones bearing the quinoline ring. Potentiometric studies. $J$ Barz Chem Soc 2006, 17:723-729.

10. Seleem HS, El-Inany GA, Mousa M, Hanafy FI: Spectroscopic studies on 2[2-(4-methylquinolin-2-yl)hydrazono]-1,2-diphenylethanone molecule and its metal complexes. Spectrochim Acta (A) 2009, 74:869-874.

11. Seleem HS, El-Inany GA, Mousa M, Hanafy FI: Spectroscopic and pH-metric studies of the complexation of 3-[2-(4-methylquinolin-2-yl)hydrazono] butan-2-one oxime compound. Spectrochim Acta (A) 2010, 75:1446-1451.

12. Taha A: Spectroscopic studies on chromotropic mixed-ligand copper(II) complexes containing o-hydroxy benzoyl derivatives and dinitrogen bases. Spectrochim Acta (A) 2003, 59:1611-1620.

13. Shebl M: Synthesis and spectroscopic studies of binuclear metal complexes of a tetradentate $\mathrm{N}_{2} \mathrm{O}_{2}$ Schiff base ligand derived from 4,6diacetylresorcinol and benzylamine. Spectrochim Acta (A) 2008, 70:850-859.

14. Seleem HS, El-Shetary BA, Khalil SME, Mostafa M, Shebl M: Structural diversity in copper(II) complexes of bis(thiosemicarbazone) and bis (semicarbazone) ligands. J Coord Chem 2005, 58:479-493.

15. Seena EB, Kurup MRP: Spectral and structural studies of mono- and binuclear copper(II) complexes of salicylaldehyde N(4)-substituted thiosemicarbazones. Polyhedron 2007, 26:829-836.

16. Singh VP: Synthesis, electronic and ESR spectral studies on copper(II) nitrate complexes with some acylhydrazines and hydrazones. Spectrochim Acta (A) 2008, 71:17-22

17. El-Asmy AA, Al-Gammal OA, Saad DA, Ghazy SE: Synthesis, characterization, molecular modeling and eukaryotic DNA degradation of 1-(3,4-dihydroxybenzylidene)thiosemicarbazide complexes. J Mol Struct 2009, 934:9-22

18. Chen Z, Wu Y, Gu D, Gan F: Nickel(II) and copper(II) complexes containing 2-(2-(5-substitued isoxazol-3-yl)hydrazono)-5,5dimethylcyclohexane-1,3-dione ligands: Synthesis, spectral and thermal characterizations. Dyes and Pigments 2008, 76:624-631.

19. Chen Z, Wu Y, Gu D, Gan F: Spectroscopic, and thermal studies of some new binuclear transition metal(II) complexes with hydrazone ligands containing acetoacetanilide and isoxazole. Spectrochim Acta (A) 2007, 68:918-826.

20. Emara AA, Seleem HS, Madyan AM: Synthesis, spectroscopic investigations, and biological activity of metal complexes of $\mathrm{N}$ benzoylthiosemicarbazide. J Coord Chem 2009, 62:2569-2582.

doi:10.1186/1752-153X-5-20

Cite this article as: Seleem et al.: The ligational behavior of an isatinic quinolyl hydrazone towards copper(II)- ions. Chemistry Central Journal 2011 5:20.

Publish with ChemistryCentral and every
scientist can read your work free of charge
"Open access provides opportunities to our
colleagues in other parts of the globe, by allowing
anyone to view the content free of charge."
W. Jeffery Hurst, The Hershey Company.
- available free of charge to the entire scientific community
- peer reviewed and published immediately upon acceptance
- cited in PubMed and archived on PubMed Central
- yours - you keep the copyright
Submit your manuscript here:
http://www.chemistrycentral.com/manuscript/

